\title{
Model matematika terapi kanker dengan viroterapi
}

(Mathematical model of cancer therapy with virotherapy)

\author{
Thariq Muhariyanto ${ }^{1 *}$, Yudi Ari Adi ${ }^{2}$ \\ ${ }^{12}$ Departemen Matematika, Fakultas Sains dan Teknologi Terapan, Universitas Ahmad Dahlan \\ Yogyakarta \\ E-mail : thariq1500015053@webmail.uad.ac.id \\ * Corresponding Author
}

\begin{tabular}{ll}
\hline ARTICLE INFO & ABSTRACT \\
\hline Kata kunci & Model merupakan penyederhanaan fenomena-fenomena nyata dalam bentuk \\
Model matematika & matematika. Salah satunya adalah model matematika pada terapi kanker \\
Viroterapi & dengan virus oncolytic atau yang disebut viroterapi. Viroterapi merupakan \\
Onkolitik & terapi kanker yang menggunakan virus sebagai terapinya. Virus yang \\
Persamma diferensial & digunakan yaitu virus onkolitik. Sistem persamaan dalam penelitian ini \\
Kestabilan & menggunakan sistem persamaan diferensial nonlinier dengan melibatkan tiga \\
Titik ekuilibrium & variabel yaitu sel tumor tidak terinfeksi x(t), sel tumor terinfeksi y(t), dan \\
Keywords & partikel virus bebas v(t). Kemudian dilakukan analisis model matematika yang \\
Mathematics Model & meliputi titik ekuilibrium, kestabilan di sekitar titik ekuilibrium, dan simulasi \\
Virotherapy & numerik. Analisis kestabilan dilakukan untuk mempelajari kedinamikan suatu \\
Oncolytic & system dengan tujuan menyelidiki jenis kestabilan dari titik-titik ekuilibrium \\
Differential Equation & pada setiap variabel dalam model, sehingga dapat diketahui kapan mencapai \\
Stability & titik keseimbangan (ekuilibrium). Hasil penelitian menunjukkan terdapat tiga \\
Equilibrium Point & titik ekuilibrium pada model matematika viroterapi yaitu E0 $(0 ; 0 ; 0), E 1(K ; 0 ;$ \\
& $0)$ dan E2. Dari model yang dibahas ukuran ledakan virus, selektivitas virus \\
& dari virus onkolitik dan ukuran tumor maksimum akan menentukan hasil dari \\
viroterapi. Ini bermakna secara biologis. Semakin besar tumor, semakin
\end{tabular}

Mathematical model of cancer therapy with virotherapy. Model is a simplification of the real phenomenon in the form of mathematics. One of the mathematic models applied in the medical sector is the cancer therapeutics mathematic model with oncolytic virus or virotherapy. Virotherapy is a form of cancer therapy that utilizes the virus as it's a therapeutic agent. The equation applied in this research uses a non-linear differential equation with three variables, which are uninfected tumor cell $\mathrm{x}(\mathrm{t})$, infected tumor celly $(\mathrm{t})$, and virus particles $v(t)$. Then, we analyze the mathematics model, which includes point of equilibrium, stability along with a moment of balance, and numerical simulation. Stability analysis is implemented to learn the dynamics of a specific system for investigating the type of serenity from the existing points of equilibrium in each model variable. The objective of this process is to determine the exact moment of balance that occurs in the system. The result of this research shows that there are 3 points of equilibrium in the virotherapy mathematics model, which are $\mathrm{E} 0(0,0,0), \mathrm{E} 1(\mathrm{~K}, 0,0)$, and $\mathrm{E} 2$. This research also analyzes the size of virus explosion, virus selectivity from oncolytic virus, and maximum tumor size to determine the virotherapy output. The bigger the size of the existing tumor, the more viruses are needed to achieve a good result of the therapy.

This is an open access article under the CC-BY-SA license.
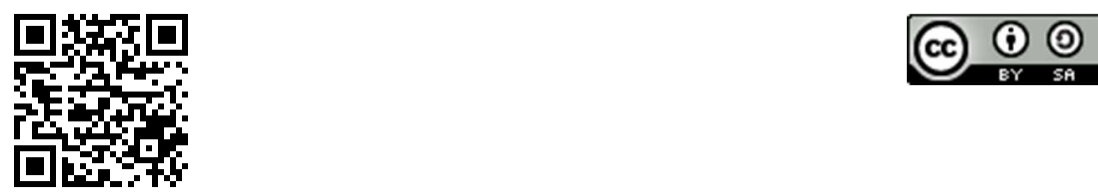


\section{PENDAHULUAN}

Pengertian Pemodelan Matematika merupakan salah satu tahap dari pemecahan masalah matematika. Model merupakan penyederhanaan fenomena-fenomena nyata dalam bentuk matematika. Model matematika yang dihasilkan, dapat berupa bentuk persamaan, pertidaksamaan, sistem persamaan atau lainnya terdiri atas sekumpulan lambang yang disebut variabel yang kemudian di dalamnya digunakan operasi matematika seperti tambah, kali, kurang, atau bagi[1]. Dengan prinsip-prinsip matematika tersebut dapat dilihat apakah model yang dihasilkan telah sesuai dengan rumusan sebagaimana formulasi masalah nyata yang dihadapi. Hubungan antara komponen-komponen dalam suatu masalah yang dirumuskan dalam suatu persamaan matematika yang memuat komponenkomponen itu sebagai variabelnya, dinamakan model matematika[2][3][4]. Proses untuk memperoleh model dari suatu masalah dikatakan pemodelan matematika. Salah satunya adalah model matematika pada terapi kanker dengan virus onkolitik atau yang disebut viroterapi[5].

Selama ini virus diasosiasikan sebagai penyebab utama terjadinya berbagai penyakit. Namun, studi terbaru menunjukkan setidaknya ada beberapa virus yang memiliki kemampuan anti kanker yang dapat digunakan untuk terapi kanker metastatis[6]. Salah satunya virus anti kanker onkolitik. Virus onkolitik adalah virus yang diubah secara genetik yang dapat menginfeksi dan bereproduksi di sel kanker, tetapi meninggalkan sel normal yang sehat tanpa cedera. Mereka saat ini sedang dikembangkan sebagai obat potensial untuk pengobatan kanker. Virus ini dipelajari karena perlakuannya terhadap sel kanker, yang mampu menginfeksi dan memecahkan sel-sel kanker tanpa merusak sel normal. Ketika disuntikkan ke dalam jaringan kanker, mereka menyerang sel kanker. Setelah lisis sel yang terinfeksi, segerombolan virus baru keluar dari sel yang mati[7][8].

Terapi tumor oleh virus onkolitik telah dan terus diuji secara aktif dalam uji klinis untuk berbagai kanker. Saat ini, meskipun menghasilkan ratusan virus infeksi per satu sel tumor yang terinfeksi, sebagian besar spesies virus tidak dapat membasmi tumor. Ada semakin banyak bukti bahwa tanggapan terhadap infeksi virus aktif memainkan peran penting dalam menentukan keefektifan viroterapi secara keseluruhan. Memang, telah terbukti bahwa system kekebalan tubuh bawaan menghancurkan sel yang terinfeksi (serta partikel virus bebas), sehingga memungkinkan tumor untuk tumbuh. Berbagai macam model matematika yang menggambarkan pertumbuhan sel tumor di bawah pengaruh virus onkolitik telah banyak dikemukakan[9] [10] [11].

Dalam tulisan ini model yang akan dibahas terdiri dari tiga populasi, yaitu populasi sel tumor belum terinfeksi, populasi sel tumor terinfeksi, populasi virus bebas[9] [10]. Model kemudian akan diselesaikan dan dianalisis secara teoritis dengan menggunakan teori-teori matematika dan disimulasikan menggunakan software MatlabR2015b untuk mengetahui interaksi sel leukemia dan sel sehat- dengan pemberian kemoterapi.

Berdasarkan uraian diatas melatar belakangi penulis sehingga melakukan penelitian yang berjudul: "Model Matematika Terapi Kanker dengan Viroterapi"

\section{METODE}

Penelitian ini merupakan studi pustaka dan studi kasus. Hal ini dilakukan untuk mendalamai, mencermati, menelaah, dan mengidentifikasi pengetahuan yang menunjang penelitian ini. Masalah yang dikaji adalah analisis kestabilan model matematika terapi kanker dengan viroterapi dimana viroterapi merupakan terapi kanker menggunakan virus onkolitik. Model yang digunakan adalah Model [9] dan [10]. Sumber-sumber yang digunakan dapat berupa buku, jurnal penelitian, skripsi, maupun internet. Studi pustaka dilakukan penelaahan sumber pustaka yang relevan dengan permasalahan yang dikaji untuk mendapatkan informasi yang diperlukan, sehingga memunculkan gagasan yang akhirnya dapat dijadikan landasan dalam melakukan penelitian[12][13][14]. Sumber pustaka yang dimaksud adalah buku-buku materi model matematika (khususnya model viroterapi), jurnal hasil penelitian sebelumnya, dan berbagai tulisan yang berkaitan dengan penelitian ini. Sedangkan studi kasus adalah melakukan simulasi dan analisis data untuk kasus nyata dengan menggunakan bantuan software Matlab-R2015b. 


\section{HASIL DAN PEMBAHASAN}

\section{Model Matematika}

Model matematika yang dibahas ialah model matematika yang dibangun dari model [9] dan [10].

Model matematika terapi kanker menggunakan virotherapy ini memiliki tiga populasi yaitu populasi sel tumor belum terinfeksi $x(t)$, populasi sel tumor terinfeksi $y(t)$, dan populasi virus bebas $v(t)$. Sistem $x(t)$ dan $y(t)$ menggunakan model Tian sedangkan sistem $v(t)$ menggunakan model Dingli. Model yang dicari adalah model yang menunjukkan perilaku virus terhadap sel tumor secara menyeluruh.

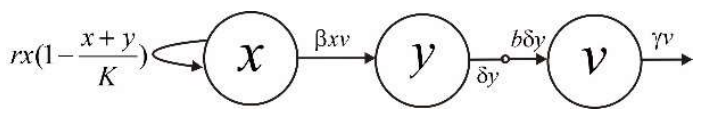

Gambar 1. Diagram Kompartemen Model Viroterapi

Model matematika terapi kanker dengan viroterapi adalah sebagai berikut :

$\frac{d x}{d t}=r x\left(1-\frac{x+y}{K}\right)-\beta x v$

$\frac{d y}{d t}=\beta x v-\delta y$

$\frac{d v}{d t}=b \delta y-\gamma v$

Model di atas harus memenuhi syarat $x ; y ; v \geq 0$.dengan $r ; \beta ; \delta ; \gamma ; b ; K>0$ : dimana:

$r$ : Laju pertumbuhan sel tumor terinfeksi

$\beta$ : Laju infeksi sel tumor oleh virus bebas

$\delta$ : Laju kematian sel tumor terinfeksi

$\gamma$ : Laju kematian partikel virus bebas

$b:$ Ukuran ledakan virus (virus baru yang keluar dari lisis)

$K$ : Ukuran maksimal tumor / Carrying capacity

Sistem $r x\left(1-\frac{x-y}{K}\right)$ mendiskripsikan tingkat pertumbuhan logistik dari popuasi sel tumor yang tidak terinfeksi $x(t)$. Dimana $r>0$ merupakan laju pertumbuhan sel tumor tidak terinfeksi secara konstan, sedangkan K merupakan ukuran maksimal dari sel tumor sehingga $x(t)+y(t) \leq K$. Hal ini menunjukkan bahwa sel tumor (jumlah populasi sel tumor belum terinfeksi dan sel tumor terinfeksi) tidak boleh melebihi ukuran maksimal tumor $(K)$. Rumus $\beta x v$ merepresentasikan laju infeksi sel tumor oleh virus bebas, dengan $\beta>0$ sebagai laju infeksi oleh virus bebas yang konstan.

Populasi sel tumor terinfeksi didiskripsikan sebagai $y(t)$ dan Populasi partikel virus bebas didiskripsikan sebagai $v(t)$. Rumus $\delta y$ merepresentasikan laju kematian sel tumor terinfeksi, dengan $\delta>$ 0 merupakan laju kematian secara konstan.

Kemampuan replikasi virus dimodelkan oleh ukuran ledakannya. Ukuran ledakan virus adalah jumlah virus baru yang dilepaskan dari lisis sel yang terinfeksi. Sehingga terdapat juga parameter $b$ yang merepresentasikan sebagai ukuran ledakan virus. Rumus $b \delta y$ merepresentasikan laju kematian sel tumor terinfeksi yang juga dipengaruhi oleh ukuran ledakan virus. Sedangkan $\gamma v$ merepresentasikan laju kematian partikel virus bebas oleh berbagai penyebab termasuk pengikatan yang tidak spesifik dan partikel generasi cacat yang mengganggu. Karena model yang dicari yaitu virus menginfeksi sel tumor terjadi secara menyeluruh sehingga laju infeksi sel tumor tidak mempengaruhi populasi partikel virus bebas.

\section{Eksistensi dan Kestabilan Titik Ekuilibrium}

Sistem (1) mempunyai tiga titik ekuilibrium yaitu: 
1. $E_{0}(0,0,0)$ merupakan titik trivial yang dalam sudut pandang medis titik ekuilibrium $E_{0}$ tidak memiliki arti.

2. $E_{1}(K, 0,0)$ dapat dikatakan eksis karena $K>0$.

3. $E_{2}\left(\frac{\gamma}{\beta b}, \frac{\gamma r(\beta b K-)}{\beta b(\gamma r+\beta b \delta K)}, \frac{\delta r(\beta b K-\gamma)}{\beta(\gamma r+\beta b)}\right) E_{2}$ dapat dikatakan esksis jika

atau

$$
\beta \mathrm{bK}-\gamma>0
$$

$$
\beta b K>\gamma
$$

Dari ketiga titik ekuilibrium yang didapat akan dilakukan analisis kestabilan titik ekuilibrium.

\section{Analisis Kestabilan Titik Ekuilibrium}

Dengan memisalkan

$$
\frac{d x}{d t}=f_{1}, \frac{d y}{d t}=f_{2}, \frac{d v}{d t}=f_{3}
$$

maka diperoleh matriks Jacobian dari sistem (1) sebagai berikut

$$
J=\left[\begin{array}{lll}
\frac{d f_{1}}{d L} & \frac{d f_{1}}{d S} & \frac{d f_{1}}{d K} \\
\frac{d f_{2}}{d L} & \frac{d f_{2}}{d S} & \frac{d f_{2}}{d K} \\
\frac{d f_{3}}{d L} & \frac{d f_{3}}{d S} & \frac{d f_{3}}{d K}
\end{array}\right]=\left[\begin{array}{ccc}
r-\frac{2 r x}{K}-\frac{r y}{K}-\beta v & -\frac{r x}{K} & -\beta x \\
\beta v & -\delta & \beta x \\
0 & b \delta & -\gamma
\end{array}\right]
$$

Teorema 1. Titik ekuilibrium bebas tumor $E_{0}$ tidak stabil.

\section{Bukti:}

Untuk $E_{0}\left(x_{0}, y_{0}, v_{0}\right)=E_{0}(0,0,0)$, diperoleh

$$
J\left(E_{1}\right)=\left[\begin{array}{ccc}
r & 0 & 0 \\
0 & -\delta & 0 \\
0 & b \delta & -\gamma
\end{array}\right]
$$

Selanjutnya akan dicari nilai eigen dari matriks Jacobiannya, yaitu

$$
\begin{gathered}
\left|\left[\begin{array}{ccc}
\lambda & 0 & 0 \\
0 & \lambda & 0 \\
0 & 0 & \lambda
\end{array}\right]-\left[\begin{array}{ccc}
r & 0 & 0 \\
0 & -\delta & 0 \\
0 & b \delta & -\gamma
\end{array}\right]\right|=0 \\
{\left[\begin{array}{ccc}
\lambda-r & 0 & 0 \\
0 & \lambda+\delta & 0 \\
0 & b \delta & \lambda+\gamma
\end{array}\right]=0} \\
(\lambda-r)(\lambda+\delta)(\lambda+\gamma)=0
\end{gathered}
$$

Maka diperoleh nilai eigen yaitu $\lambda_{1}=r, \lambda_{2}=-\delta, \lambda_{3}=\gamma$ sehingga titik $E_{0}$ tidak stabil karena $\lambda 1$ bernilai positif.

Teorema 2. Titik ekuilibrium $E_{1}$ stabil asimtotik jika;

(a) $A>0, B>0$, dan $C>0$.

(b) $A B-C>0$.

Dengan

$A=r+\delta+\gamma$ 


$$
\begin{aligned}
& B=r \delta+r \gamma+\delta \gamma-b \delta \beta K \\
& C=r \delta \gamma-r b \delta \beta K
\end{aligned}
$$

\section{Bukti:}

Untuk $E_{1}(K, 0,0)$ diperoleh

$$
J\left(E_{1}\right)=\left[\begin{array}{ccc}
-r & -r & -\beta K \\
0 & -\delta & \beta K \\
0 & b \delta & -\gamma
\end{array}\right]
$$

Selanjutnya akan dicari nilai eigen dari matriks Jacobiannya, yaitu:

$$
\begin{gathered}
\left|\lambda I-J\left(E_{1}\right)\right|=0 \\
\left|\left[\begin{array}{ccc}
\lambda & 0 & 0 \\
0 & \lambda & 0 \\
0 & 0 & \lambda
\end{array}\right]-\left[\begin{array}{ccc}
-r & -r & -\beta K \\
0 & -\delta & \beta K \\
0 & b \delta & -\gamma
\end{array}\right]\right|=0 \\
\left|\left[\begin{array}{ccc}
\lambda+r & r & \beta K \\
0 & \lambda+\delta & -\beta K \\
0 & -b \delta & \lambda+\gamma
\end{array}\right]\right|=0 \\
(\lambda+r)(\lambda+\delta)(\lambda+\gamma)-(-b \delta)(-\beta K)(\lambda+r)=0 \\
\lambda^{3}+\lambda^{2}(r+\delta+\gamma)+\lambda(r \delta+r \gamma+\delta \gamma-b \delta \beta K)+r \delta \gamma-r b \delta \beta K=0
\end{gathered}
$$

Diperoleh nilai eigen menggunakan kriteria Routh-Hurwitz sebagai berikut;

Misalkan:

$A=r+\delta+\gamma$

$B=r \delta+r \gamma+\delta \gamma-b \delta \beta K$

$C=r \delta \gamma-r b \delta \beta K$

Matriks Hurwitz yang dihasilkan adalah

$$
H=\left[\begin{array}{lll}
A & 1 & 0 \\
C & B & A \\
0 & 0 & C
\end{array}\right]
$$

Dari matriks H diperoleh:

$$
\begin{gathered}
\Delta_{1}=|A| \\
\Delta_{2}=\left|\begin{array}{ll}
A & 1 \\
C & B
\end{array}\right|=A B-C \\
\Delta_{3}=\left|\begin{array}{lll}
A & 1 & 0 \\
C & B & A \\
0 & 0 & C
\end{array}\right|=A B C>0 .
\end{gathered}
$$

Jadi semua akar polynomial $\lambda^{3}+A \lambda^{2}+B \lambda+C=0$ mempunyai bagian real negative jika;

(a) $A>0, B>0$, dan $C>0$.

(b) $A B-C>0$.

Teorema 3. Titik ekuilibrium $E_{2}$ stabil asimtotik jika;

(a) $D>0, E>0$, dan $F>0$.

(b) $D E-F>0$.

\section{Dengan}

$$
\begin{aligned}
& D=-s+t+u \\
& E=-s t-s u+t u-b \delta \beta x^{*}+\beta x^{*} \frac{r x^{*}}{K} \\
& F=-s t u+\beta^{2} b \delta x^{*} v^{*}+s b \delta \beta x^{*}+u \beta v^{*} \frac{r x^{*}}{K} \\
& s=r-\frac{2 r x^{*}}{K}-\frac{r y^{*}}{K}-\beta v^{*} \\
& t=\delta
\end{aligned}
$$




$$
\begin{aligned}
& u=\gamma \\
& x^{*}=\frac{\gamma}{\beta b} \\
& y^{*}=\frac{\gamma r(\beta b K-\gamma)}{\beta b(\gamma r+\beta b \delta K)} \\
& v^{*}=\frac{\delta r(\beta b K-\gamma)}{\beta(\gamma r+\beta b \delta K)}
\end{aligned}
$$

\section{Bukti:}

Untuk $E_{2}\left(\frac{\gamma}{\beta b}, \frac{\gamma r(\beta b K-\gamma)}{\beta b(\gamma r+\beta b \delta K)}, \frac{\delta r(\beta b K-\gamma)}{\beta(\gamma r+\beta b \delta K)}\right)$ diperoleh

$$
J\left(E_{2}\right)=\left[\begin{array}{crc}
r-\frac{2 r x^{*}}{K}-\frac{r y^{*}}{K}-\beta v^{*} & -\frac{r x^{*}}{K} & -\beta x^{*} \\
\beta v^{*} & -\delta & \beta x^{*} \\
0 & b \delta & -\gamma
\end{array}\right]
$$

Misalkan

$$
\begin{aligned}
& s=r-\frac{2 r x^{*}}{K}-\frac{r y^{*}}{K}-\beta v^{*} \\
& t=\delta \\
& u=\gamma
\end{aligned}
$$

Selanjutnya akan dicari nilai eigen dari matriks Jacobian tersebut, sebagai berikut

$$
\begin{gathered}
\left.\mid \begin{array}{lll}
\lambda & 0 & 0 \\
0 & \lambda & 0 \\
0 & 0 & \lambda
\end{array}\right]-\left[\begin{array}{ccc}
s & -\frac{r x^{*}}{K} & -\beta x^{*} \\
\beta v^{*} & -t & \beta x^{*} \\
0 & b \delta & -u
\end{array}\right] \mid=0 \\
\left.\qquad \mid \begin{array}{ccc}
\lambda-s & \frac{r x^{*}}{K} & \beta x^{*} \\
-\beta v^{*} & \lambda+t & -\beta x^{*} \\
0 & -b \delta & \lambda+u
\end{array}\right] \mid=0 \\
(\lambda-s)(\lambda+t)(\lambda+u)+\left(\beta x^{*}\right)\left(-\beta v^{*}\right)(-b \delta)-(-b \delta)\left(-\beta x^{*}\right)(\lambda-s)-(\lambda+u)\left(-\beta v^{*}\right)\left(\frac{r x^{*}}{K}\right)=0 \\
\left(\lambda^{3}+\lambda^{2}(-s+t+u)+\lambda\left(-s t-s u+t u-b \delta \beta x^{*}+\beta x^{*} \frac{r x^{*}}{K}\right)-s t u+\beta^{2} b \delta x^{*} v^{*}+s b \delta \beta x^{*}\right. \\
+u \beta v^{*} \frac{r x^{*}}{K}=0
\end{gathered}
$$

Maka diperoleh nilai eigen menggunakan kriteria Routh-Hurwitz sebagai berikut;

Misalkan

$$
\begin{aligned}
& D=-s+t+u \\
& E=-s t-s u+t u-b \delta \beta x^{*}+\beta x^{*} \frac{r x^{*}}{K} \\
& F=-s t u+\beta^{2} b \delta x^{*} v^{*}+s b \delta \beta x^{*}+u \beta v^{*} \frac{r x^{*}}{K}
\end{aligned}
$$

Matriks Hurwitz yang diperoleh

Dari matriks H diperoleh

$$
H=\left[\begin{array}{lll}
A & 1 & 0 \\
C & B & A \\
0 & 0 & C
\end{array}\right]
$$

$$
\begin{gathered}
\Delta_{1}=|D| \\
\Delta_{2}=\left|\begin{array}{ll}
D & 1 \\
F & E
\end{array}\right|=D E-F \\
\Delta_{3}=\left|\begin{array}{llr}
D & 1 & 0 \\
F & E & D \\
0 & 0 & F
\end{array}\right|=D E F>0 .
\end{gathered}
$$


Jadi semua akar polynomial $\lambda^{3}+D \lambda^{2}+E \lambda+F=0$ mempunyai bagian real negatif jika;

(a) $D>0, E>0$, dan $F>0$.

(b) $D E-F>0$.

\section{Simulasi Numerik}

Simulasi dilakukan menggunakan program Matlab R2015b dengan memberikan nilai-nilai untuk masing-masing parameter. Karena pada model dianggap sebagai populasi sel, volume tumor diubah menjadi populasi sel dengan diasumsikan bahwa $1 \mathrm{~mm}^{3}$ sesuai dengan $10^{6}$ sel. Sehingga populasi sel dan virus $\mathrm{x}, \mathrm{y}$ dan $\mathrm{v}$ dinyatakan dalam $10^{6} \mathrm{sel}$ atau unit.

Proses simulasi dilakukan dengan menggunakan data sebagai berikut:

Tabel 1. Nilai Parameter

\begin{tabular}{ccll}
\hline Simbol & Nilai Estimasi & Satuan & Sumber \\
\hline$r$ & 0.206 & hari $^{-1}$ & Dingli(2006) \\
$\beta$ & 0.01 & hari $^{-1}$ & Dingli(2006) \\
$\delta$ & 0.05 & hari $^{-1}$ & Dingli(2006) \\
$\gamma$ & 0.32 & hari $^{-1}$ & Asumsi \\
$K$ & 213 & sel & Asumsi \\
\hline
\end{tabular}

dengan nilai awal

$$
x(0)=122 \mathrm{sel} ; y(0)=25 \mathrm{sel} ; v(0)=30 \mathrm{sel} .
$$

Untuk melihat pengaruh dari pemberian viroterapi terhadap sel tumor belum terinfeksi, simulasi dilakukan untuk berbagai ukuran ledakan virus (b) dengan menggunakan nilai parameter pada Tabel 1 dan nilai awal pada persamaan (2) diperoleh dinamika sistem untuk beberapa ukuran ledakan virus yang berbeda.
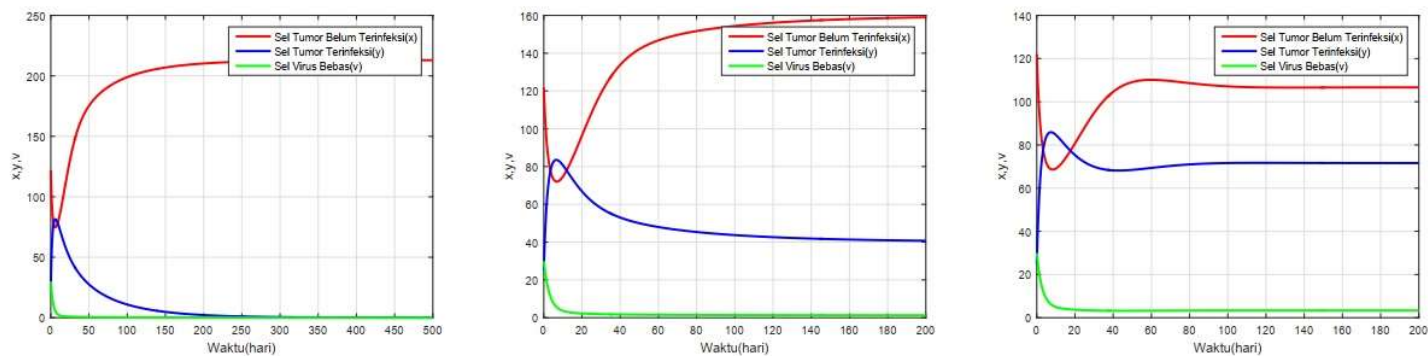

Gambar 2. Simulasi numerik $b=0.1, b=0.2$, dan $b=0.3$.
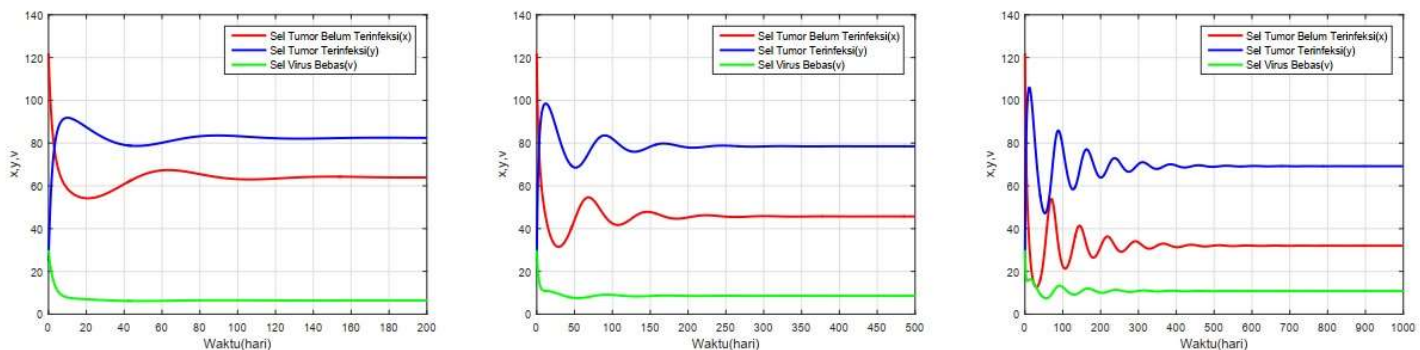

Gambar 3. Simulasi numerik $b=0.5, b=0.7$ dan $b=1$. 

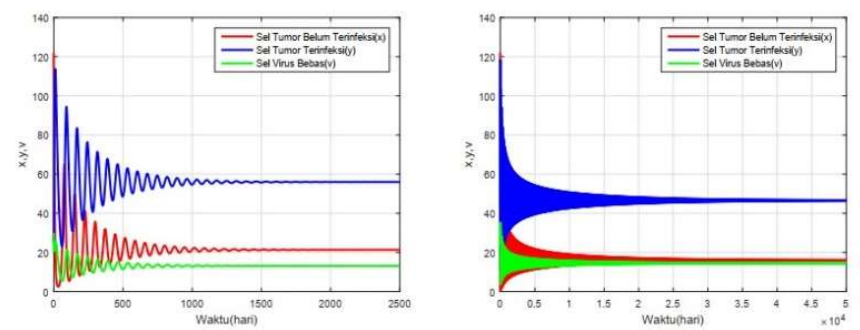

Gambar 4. Simulasi numerik $b=1.5$ dan $b=2$.
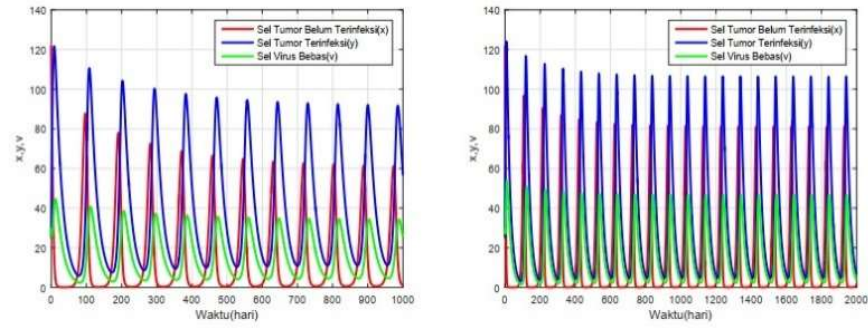

Gambar 5. Simulasi numerik $b=2.5$ dan $b=3$.

Gambar 2, 3, 4 dan 5 merupakan hasil simulasi numerik dari model viroterapi dengan nilai parameter yang sudah ditentukan pada tabel 1 dan dengan nilai awal pada persamaan (2) serta berbagai nilai parameter $b$. Pada hasil simulasi numerik diatas menunjukkan bahwa dengan $\mathrm{b}=0,1$ sistem mendekati titik ekuilibrium $E_{0}$ yaitu sel tumor terinfeksi dan partikel virus bebas tidak terdapat dalam tubuh yang mana secara medis kondisi viroterapi tidak berjalan dengan baik. Sedangkan dengan $b=0,2$ sampai 2 menunjukkan system mendekati titik ekuilibrium $E_{1}$. Ketika $\mathrm{b}=0,2$ dan $\mathrm{b}=0,3$ jumlah populasi sel tumor belum terinfeksi masih diatas populasi sel tumor terinfeksi menunjukkan bahwa pemberian viroterapi belum efektif mengendalikan laju pertumbuhan sel tumor. Pada $b=0,5$ sampai 2 menunjukkan pemberian viroterapi dapat membantu mengendalikan laju pertumbuhan sel tumor walaupun sel tumor masih terdapat di dalam tubuh ditunjukkan dengan naiknya laju inveksi virus terhadap sel tumor. Namun demikian, karena sudah diketahui gambaran kondisi penderita maka akan lebih baik lagi jika diberikan pengobatan selanjutnya.

Dari hasil simulasi numerik, semakin besar nilai $b$ atau semakin besar ledakan virus baru dari lisis maka akan semakin lama grafik mencapai stabil, akan tetapi ketika nilai $b>2$, grafik akan menjadi periodik. Dilihat pada hasil simulasi numerik pada gambar 2, 3, 4 dan 5 yang menunjukkan bahwa grafik dengan nilai $\mathrm{b} \leq 2$ akan mencapai stabil. Sedangkan gambar 5 menunjukkan bahwa ketika nilai $b>2$ grafik akan menjadi priodik. Hal ini disebabkan karena nilai parameter $\mathrm{b}>2$ sudah tidak memenuhi syarat kestabilan untuk titik ekuilibrium $E_{2}$.
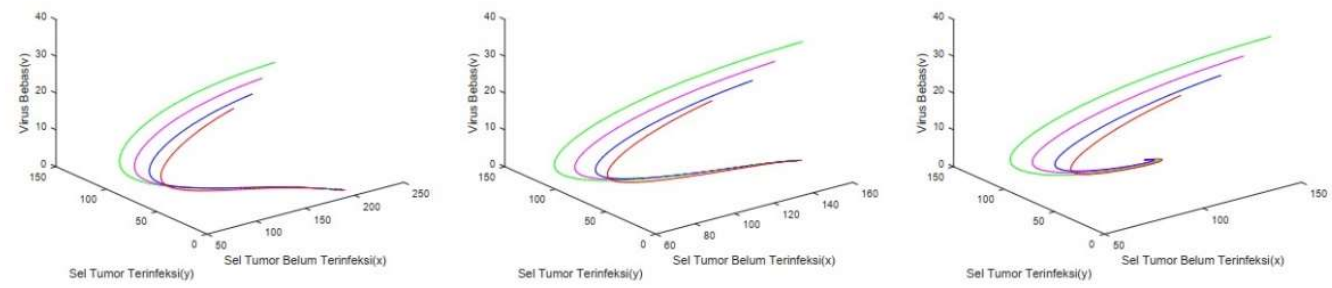

Gambar 6. Potret fase sistem untuk $b=0.1, b=0.2$ dan $b=0.3$. 

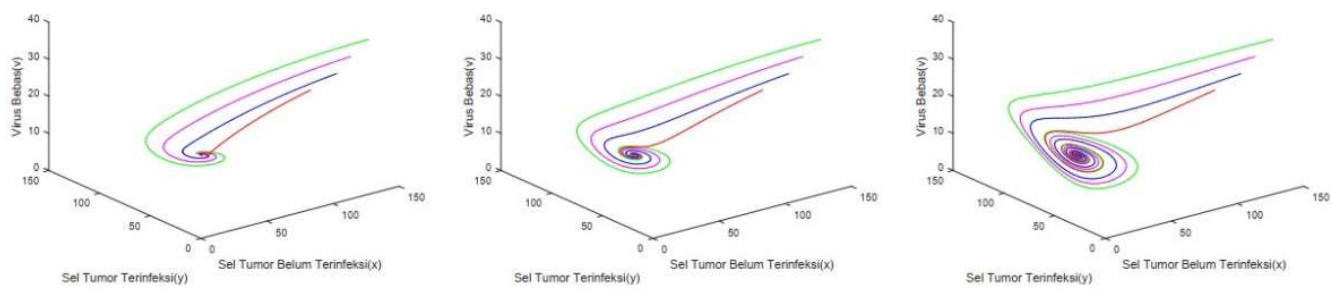

Gambar 7. Potret fase sistem untuk $b=0.5, b=0.7$ dan $b=1$
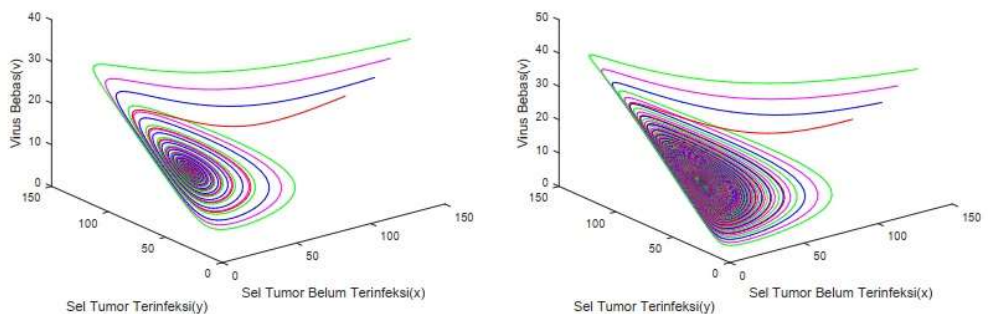

Gambar 8. Potret fase sistem untuk $b=1.5$ dan $b=2$.
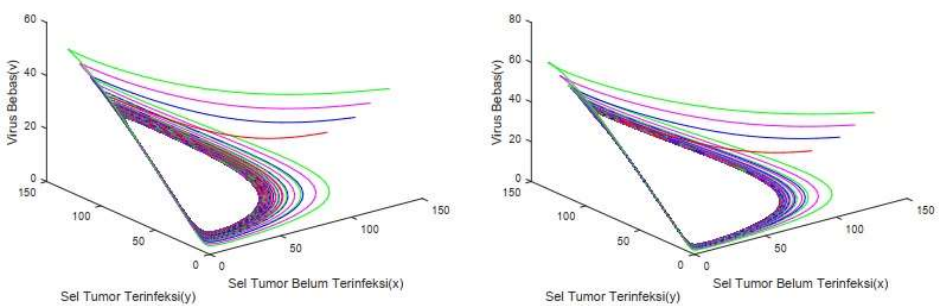

Gambar 9. Potret fase sistem untuk $b=2.5$ dan $b=3$.

Gambar 6, 7, 8 dan 9 merupakan potret fase dari model viroterapi dengan nilai parameter yang sudah ditentukan pada tabel 1 dan dengan nilai awal pada persamaan (2) serta berbagai nilai parameter $b$. Pada gambar 6, 7 dan 8 dapat dilihat bahwa grafik menuju ke satu titik. Hal ini menunjukkan bahwa pada saat $b \leq 2$ sistem bersifat stabil asimtotik yang artinya apabila laju pertumbuhan sel tumor tetap dapat dikendalikan, maka viroterapi pada kondisi ini berjalan dengan baik. Pada gambar 9 grafik potret fase akan terus berputar tanpa menuju ke satu titik. Dikarenakan jika nilai parameter $b>2$ sudah tidak memenuhi syarat kestabilan untuk titik ekuilibrium $E_{2}$. Artinya viroterapi tidak berkerja dengan baik. Dari simulasi numerik model viroterapi dengan nilai parameter dan nilai awal yang sudah ditentukan, menunjukkan bahwa ukuran ledakan virus (virus baru yang keluar dari lisis) mempengaruhi laju pertumbuhan sel tumor belum terinfeksi dan sel tumor belum terinfeksi. Ketika $b \leq 2$ sistem mengalami kestabilan asimtotik sedangkan ketika $b>2$ solusi mengalami keperiodikan.

\section{SIMPULAN}

1. Sistem persamaan model viroterapi atau terapi tumor dengan pemberian virus onkolitik yang dihasilkan yaitu

$$
\begin{gathered}
\frac{d x}{d t}=r x\left(1-\frac{x+y}{K}\right)-\beta x v \\
\frac{d y}{d t}=\beta x v-\delta y \\
\frac{d v}{d t}=b \delta y-\gamma v
\end{gathered}
$$

yang terdiri dari tiga persamaan dengan tiga variabel dan enam parameter.

2. Model viroterapi diatas menghasilkan tiga titik ekuilibrium yaitu $E_{0}(0,0,0)$ yang tidak stabil, $E_{1}(K, 0,0)$ dan $E_{2}\left(\frac{\gamma}{\beta b}, \frac{\gamma r(\beta b K-\gamma)}{\beta b(\gamma r+\beta b)}, \frac{\delta r(\beta b K-\gamma)}{\beta(\gamma r+\beta b \delta K)}\right)$ stabil asimtotik jika memenuhi syarat eksistensi dan kestabilan tertentu. Dimana pada titik ekuilibrium $E_{0}(0,0,0)$ kondisi populasi sel 
tumor tidak terinfeksi dan sel tumor terinfeksi tidak terdapat dalam tubuh yang secara medis tidak memiliki arti. Pada titik ekuilibrium $E_{1}(K, 0,0)$ memperlihatkan kondisi dimana populasi sel tumor terinfeksi dan populasi partikel virus bebas berjumlah 0 atau tidak ada partiker virus bebas yang menginfeksi sel tumor artinya viroterapi tidak berjalan dengan baik. Pada titik ekuilibrium $E_{2}\left(\frac{\gamma}{\beta b}, \frac{\gamma r(\beta b K-\gamma)}{\beta b(\gamma r+\beta b \delta K)}, \frac{\delta r(\beta b K-\gamma)}{\beta(\gamma r+\beta b \delta K)}\right)$ memperlihatkan bahwa viroterapi dapat membantu mengendalikan laju pertumbuhan sel tumor.

3. Simulasi numerik yang dilakukan dengan berbagai ukuran ledakan virus (b) dengan menggunakan nilai parameter pada Tabel 1 dan nilai awal pada persamaan (2) diperoleh dinamika sistem untuk beberapa ukuran ledakan virus yang berbeda. Hasilnya menunjukan pada saat nilai parameter $b \leq 2$ sistem akan stabil asimtotik sedangkan pada saat nilai parameter $b>$ 2 sistem mengalami periodik dan tidak menuju ke satu titik. Hal ini dikarenakan, nilai parameter $b>2$ sudah tidak memenuhi syarat kestabilan untuk titik ekuilibrium $E 2$ yang artinya viroterapi tidak berjalan dengan baik.

4. Dari model yang dibahas ukuran ledakan virus, selektivitas virus dari virus onkolitik dan ukuran tumor maksimum akan menentukan hasil dari viroterapi. Ini bermakna secara biologis. Semakin besar tumor, semakin banyak virus kuat diperlukan untuk melawannya.

\section{DAFTAR PUSTAKA}

[1] W. E. Boyce, R. C. DiPrima, and D. B. Meade, Elementary differential equations. John Wiley \& Sons, 2017.

[2] Ž. Bajzer, T. Carr, K. Josić, S. J. Russell, and D. Dingli, "Modeling of cancer virotherapy with recombinant measles viruses," J. Theor. Biol., vol. 252, no. 1, pp. 109-122, 2008.

[3] A. Friedman and C.-Y. Kao, Mathematical modeling of biological processes. Springer, 2014.

[4] S. Kusmaryanto, Matematika Teknik I. Universitas Brawijaya Press, 2013.

[5] F. R. Giordano, M. D. Weir, and W. P. Fox, "Mathematical modeling," ThomsonBrookes/Cole, 2003.

[6] R. Haberman, Mathematical models: mechanical vibrations, population dynamics, and traffic flow. SIAM, 1998.

[7] D. Ruelle, Elements of differentiable dynamics and bifurcation theory. Elsevier, 2014.

[8] A. E. Laaroussi, M. El Hia, M. Rachik, E. Benlahmar, and Z. Rachik, "Analysis of a mathematical model for treatment of cancer with oncolytic virotherapy," Appl. Math. Sci, vol. 8, pp. 929-940, 2014.

[9] D. Dingli, M. D. Cascino, K. Josić, S. J. Russell, and Ž. Bajzer, "Mathematical modeling of cancer radiovirotherapy," Math. Biosci., vol. 199, no. 1, pp. 55-78, 2006.

[10] J. P. Tian, "The replicability of oncolytic virus: defining conditions in tumor virotherapy," Math. Biosci. Eng., vol. 8, no. 3, p. 841, 2011.

[11] H. Anton, P. Silaban, and I. N. Susila, Aljabar Linear Elementer. Erlangga, Jakarta, 1987.

[12] L. Perko, "Linear systems," in Differential Equations and Dynamical Systems, Springer, 1991, pp. 1-63.

[13] M. Braun and M. Golubitsky, Differential equations and their applications, vol. 1. Springer, 1983.

[14] A. Tsoularis and J. Wallace, "Analysis of logistic growth models," Math. Biosci., vol. 179, no. 1, pp. 21-55, 2002. 